\title{
Behaviour of Rendering Mortar for Rehabilitation of Buildings Subjected to Rising Damp
}

\author{
Paulo Cabana Guterres ${ }^{1}$ and Luiz Pereira de Oliveira $^{2}$ \\ 1. Civil Engineering College, Federal University of Uberlândia, Uberlândia, Minas Gerais, Brazil; \\ 2. Centre of Materials and Building Technologies, University of Beira Interior, Covilhã, Portugal
}

\begin{abstract}
This paper presents an experimental study on the behaviour of rendering mortars used to rehabilitate buildings subjected to rising damp and consequently affected by efflorescence. This study was initiated by the characterization, "in situ" and in laboratory, of rendering mortar used as walls coating of an old building affected by efflorescence. Temperature, superficial humidity, mortar water content and salts content were used as characterization tests. Taking into account the reconstitution of old building rendering mortar composition, four different proportions were proposed to simulate different mortars skeletons and porosities. The mortars binders were composed by cement and three additions, such as hydrated lime, artificial hydraulic lime and quicklime paste. The results of capillary water absorption, soluble salts content and permeability test on masonry panels allowed analyzing the performance of mortars compared to the susceptibility of water rise and formation of salts. From this analysis, it was possible to draw some practical recommendations for design coating repair mortar in buildings subject to the problem of rising damp.
\end{abstract}

Key words: Rehabilitation, rendering mortar, rising damp, capillarity, water permeability, soluble salts.

\section{Introduction}

A survey of the buildings conservation status belonging to the central perimeter of Pelotas city, Rio Grande do Sul State, Brazil, according Paladini criteria [1], shows that almost half of the facades, i.e., 189 facades $(44.6 \%)$ have a good condition of conservation. Very good condition is identified in $66(15.6 \%)$ facades, in steady state are $156(36.8 \%)$ facades and in bad state are 13 facades (3.1\%). These facades have been shown from 0 to 1 typical anomalies distributed asymmetrically, where $212(50.0 \%)$ facades had 3 or more anomalies. From the identified deficiencies, the results show that the rising damp corresponds to $17.2 \%$ of the anomalies.

Temperature and surface humidity measurements on the old buildings walls were held in 2000, in different periods (May, June and July) and always in the same time band. The results showed average values of $15^{\circ} \mathrm{C}$ $\pm 1{ }^{\circ} \mathrm{C}$ and $75 \% \pm 4 \% \mathrm{RH}$ (relative humidity).

Corresponding author: Paulo Cabana Guterres, professor, dr.; research fields: construction materials. E-mail: prcguterres@gmail.com,paulo.guterres@ufu.br.
Rendering mortar samples extracted from the buildings walls were characterized in terms of components and proportions, it has been determined that these mortars were constituted of lime (quicklime) and natural sand from Arroio Pelotas with various mass proportions as: $1: 4,1: 5,1: 6$ and $1: 12$.

In this study, an experimental plan was designed to evaluate the mortars susceptibility to rising damp action, to transport soluble salts and to develop anomalies by efflorescence and/or crypto-efflorescence.

\section{Experimental Program}

The reconstitution of rendering mortars from the buildings walls of the historic center of Pelotas enables to define a reference mortar and a cement based mortars incorporating three types of lime: quicklime, hydrated lime and artificial hydraulic lime. The materials used in mortars were selected in view of its technical characteristics and availability in the domestic market, giving emphasis to those of traditional use and facility to obtain in Pelotas city. 


\subsection{Materials}

A pozzolanic Portland cement CP IV 32, according to NBR $5736 / 1991$ [2], with a density $2,700 \mathrm{~kg} / \mathrm{m}^{3}$ and Blaine fineness of $416 \mathrm{~m}^{2} / \mathrm{kg}$ was used. An hydrated lime with density $0.553 \mathrm{~kg} / \mathrm{m}^{3}$, an artificial hydraulic lime incorporating rice husk ash with density $0.644 \mathrm{~kg} / \mathrm{m}^{3}$ and a quicklime (non hydrated) with density $0.913 \mathrm{~kg} / \mathrm{m}^{3}$ were used as additions. The sand used in this study was selected in manner to simulate the best sand identified in mortar reconstitution process applied in the original render of some of the buildings in the historic centre of Pelotas. The selected sand was natural river sand from the Arroio Pelotas with low impurities content, with density $1,484 \mathrm{~kg} / \mathrm{m}^{3}$, maximum size $4.8 \mathrm{~mm}$ and fineness modulus 2.77 .

\subsection{Mortars}

The rendering mortar mass proportions 1:1:6 (cement:lime:sand) typically used in Pelotas, which corresponds to more approximate proportions values found in mortars reconstitution of the buildings in the historic center of Pelotas, was chosen as the reference mortar. In the other mixtures, here studied, the type of addition was varied to compose the following binders: cement + hydrated lime (CHA), cement + artificial hydraulic lime (CHB) and cement + quicklime paste (CV). Table 1 summarizes the quantities of materials used for the different mortars proportions. The amount of water obtained in the reference mortar (1:1:6) using the flow table test (consistency test) was fixed as the quantity necessary to attain an average spread diameter of $167 \mathrm{~mm}$ ( $67 \%$ above the cone base diameter). To achieve this consistency value, $200 \mathrm{~mL}$ of water was used, which corresponds to $13 \%$ of the volume of material used in the reference mortar. This water quantity was fixed and applied to others mortars (1:0.33:3.7-1:1:7-1:4:14), regardless of the different additions types.

\subsection{Methods}

The voids index of hardened rendering mortars was determined on three cylindrical specimens $(50 \mathrm{~mm}$ in diameter and $100 \mathrm{~mm}$ in height) for each type of mortar taking into account the water absorption method according to NBR 9778/1987 [3].

The capillary water absorption test was performed on prismatic specimens with dimensions of $40 \mathrm{~mm} \times$ $40 \mathrm{~mm} \times 160 \mathrm{~mm}$. The specimens used in the test were first conditioning during 28 days in a curing chamber and after the specimens were submitted a drying-wetting procedure till the age of 240 days. These conditions were considered close to those that mortar will present when the buildings are subjected to climatic effects. The applied test method is described in the report 140/00-NCCT LNEC [4]. Fig. 1 illustrates a sequence of the test procedure involving the determination of the dry mass, the water contact of test specimens and periodic weighing after contact.

The compressive strengths at 7 and 28 days were determined on 6 cylindrical samples $(50 \mathrm{~mm}$ diameter and $100 \mathrm{~mm}$ height) according to NBR 7215 [5]. The tensile strength in bending on prismatic specimens was determined at 28 days, according to the NBR 12142 [6].

The measurement of water absorption under low pressure (water permeability) test was applied on masonry panels coated with the mortars studied, as shown in Fig. 2, according to the "pipe method" described by Polisseni [8].

Table 1 Compositions and proportions of mortars.

\begin{tabular}{lllllll}
\hline $\begin{array}{l}\text { Mortar mass } \\
\text { proportions }\end{array}$ & Cement $(\mathrm{g})$ & Lime $(\mathrm{g})$ & Sand $(\mathrm{g})$ & Water $(\mathrm{g})$ & $\begin{array}{l}\text { Water/cement } \\
\text { ratio }\end{array}$ & $\begin{array}{l}\text { Water/binder } \\
\text { ratio }\end{array}$ \\
\hline $1: 1: 6$ & 193 & 193 & 1154 & 200 & 1.04 & 0.52 \\
$1: 0.33: 3.7$ & 306 & 106 & 1128 & 200 & 0.65 & 0.49 \\
$1: 1: 7$ & 171 & 171 & 1197 & 200 & 1.17 & 0.58 \\
$1: 4: 14$ & 81 & 324 & 1135 & 200 & 2.40 & 0.48 \\
\hline
\end{tabular}



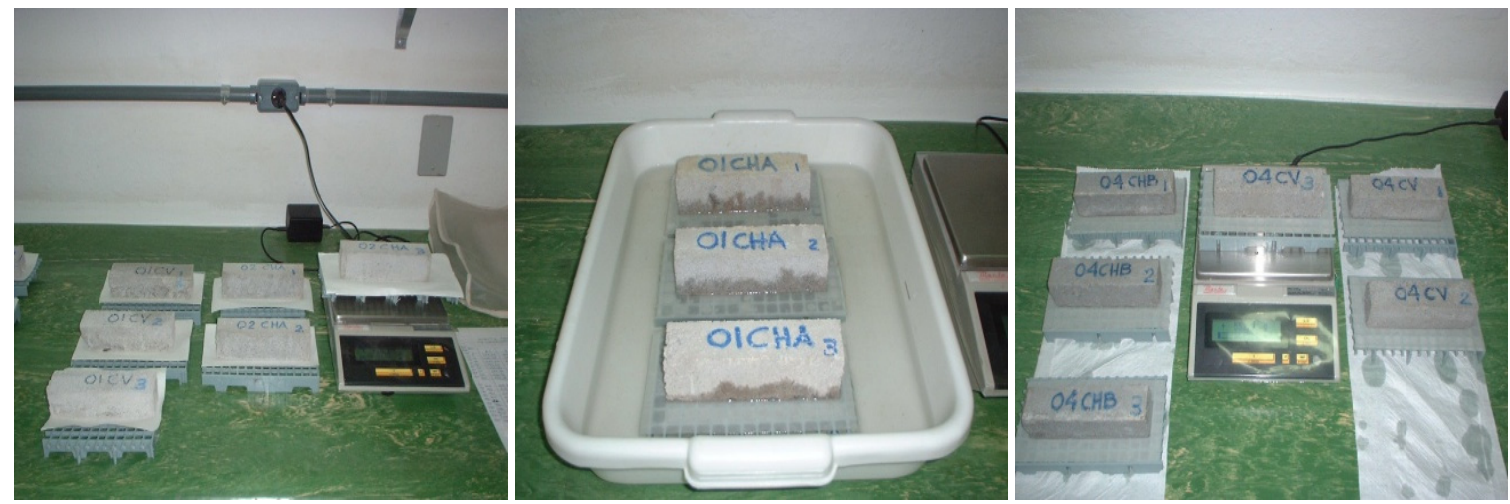

Fig. 1 Water capillarity absorption test procedure.
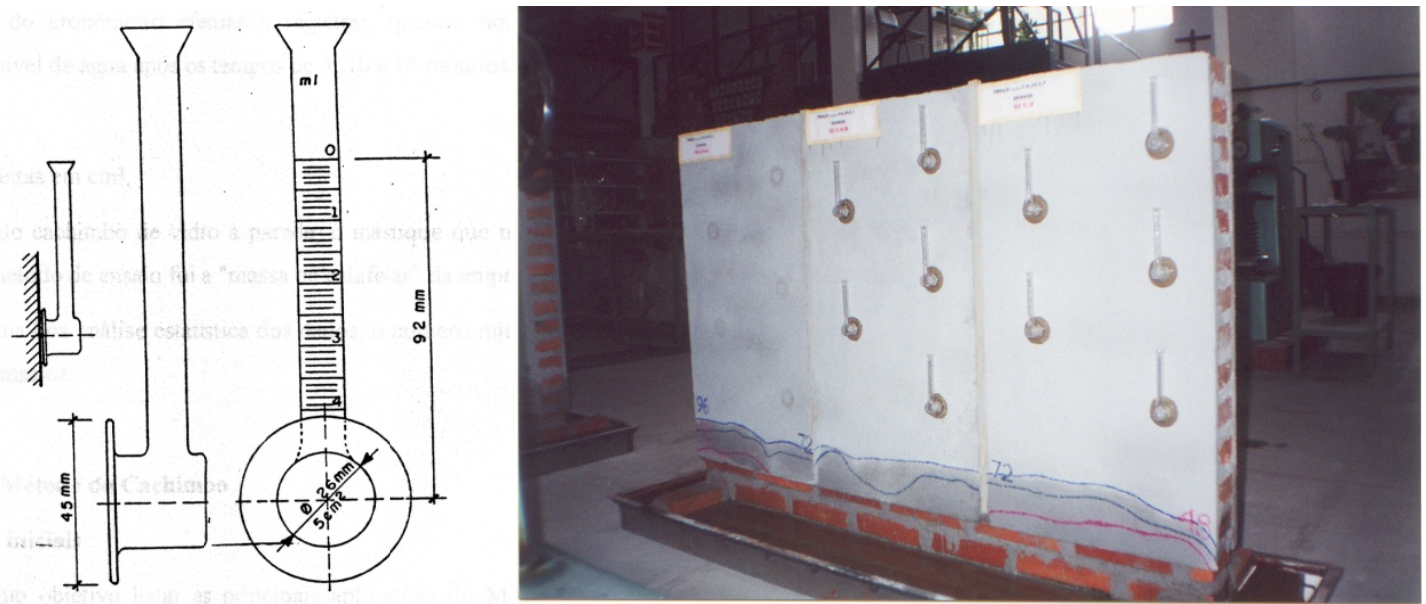

Fig. 2 Water permeability testing on panels coated with mortar.

In this method, the measurement of mortar water absorption is carried out under an initial pressure due to a water column height of $92 \mathrm{~mm}$, which corresponds to static action with wind speed about $0.28 \mathrm{~m} / \mathrm{s}$, where the height of the column corresponds to the water pressure $\left(\mathrm{kgf} / \mathrm{m}^{2}\right)$ exerted by this column (1 mm water column corresponds to $1 \mathrm{kgf} / \mathrm{m}^{2} \cong 10 \mathrm{~Pa}$ ).

The determination of soluble salts content in rendering mortar samples extracted from the masonry panels produced in the laboratory was performed according to NBR 9917/1987 [9]. After the panels have been subjected to the action of water containing $5 \%$ sodium sulphate for a period of 24 months, the mortar specimens were extracted from masonry panels with a cup-saw tool. The mortars specimens showing no visually efflorescence and/or crypto-efflorescence were subjected to a test to determine the internal salts content.

\section{Results and Discussion}

The results obtained were analyzed using the ANOVA statistical test. The variables as mortar binder type and mortar proportions, presented in Table 2, were compared with each other at different levels. The statistical test used chooses a comparison variable for the purpose of solving the probability of no significant difference between them. In the case of binder type, the cement + quicklime rendering mortar $(\mathrm{CV})$ was fixed as reference and in the case of mortar proportion it was the mortar proportion 1:4:14.

The results of the effects analysis on voids ratio presented in Table 3 confirms with probability $p<0.05$ that among them, only a level of mortar proportion variable 1:1:7 was not significantly distinguishable from the effects of the others evaluated variables. The numbers identified as "parameter" in the third column 
Table 2 Mortars variables.

\begin{tabular}{llll}
\hline Column & Mortar variable & Variable level & Versus level \\
\hline 1 & Binder type & CHA & CV \\
2 & Binder type & CHB & CV \\
3 & Proportion & $1: 1: 6$ & $1: 4: 14$ \\
4 & Proportion & $1: 0.33: 3.7$ & $1: 4: 14$ \\
5 & Proportion & $1: 1: 7$ & $1: 4: 14$ \\
\hline
\end{tabular}

Table 3 Results of variables effects analysis on mortars voids ratio.

\begin{tabular}{llllll}
\hline Level effect & Column & Parameter & Std.Err & $t$ & $p$ \\
\hline CHA & 1 & -0.2658 & 0.1202 & -2.210 & 0.034 \\
CHB & 2 & -0.5358 & 0.1202 & -4.456 & 0.000 \\
$1: 1: 6$ & 3 & -0.6736 & 0.1472 & -4.574 & 0.000 \\
$1: 0.33: 3.7$ & 4 & -0.7102 & 0.1472 & -4.823 & 0.000 \\
$1: 1: 7$ & 5 & -0.2213 & 0.1472 & -1.503 & 0.143 \\
\hline
\end{tabular}

$p=$ probability of variable significance, $p<0.05$.

Table 4 Results of variables effects analysis on mortars coefficient of capillarity.

\begin{tabular}{llllll}
\hline Level effect & Column & Parameter. & Std.Err & $\mathrm{t}$ & $\mathrm{p}$ \\
\hline CHA & 1 & 0.0259 & 0.0244 & 1.059 & 0.297 \\
CHB & 2 & -0.0450 & 0.0244 & -1.839 & 0.075 \\
$1: 1: 6$ & 3 & $-0,0378$ & 0.0299 & -1.262 & 0.216 \\
$1: 0.33: 3.7$ & 4 & -0.1055 & 0.0299 & -3.522 & 0.001 \\
$1: 1: 7$ & 5 & -0.0402 & 0.0299 & -1.341 & 0.189 \\
\hline
\end{tabular}

Table 5 Results of variables effects analysis on mortars compressive and flexure strengths at 28 days.

\begin{tabular}{llllllllll}
\hline \multirow{2}{*}{ Level effect } & \multirow{2}{*}{ Column } & \multicolumn{4}{c}{ Compressive strength } & \multicolumn{4}{c}{ Flexure strength } \\
\cline { 3 - 10 } & & Parameter & Std.Err & $t$ & $p$ & Parameter & Std.Err & $t$ & $p$ \\
\hline CHA & 1 & 0.2594 & 0.3700 & 0.701 & 0.488 & 0.1902 & 0.0510 & 3.725 & 0.000 \\
CHB & 3 & -0.4147 & 0.3700 & -1.120 & 0.271 & -0.0530 & 0.0510 & -1.038 & 0.307 \\
$1: 1: 6$ & 3 & 0.0961 & 0.4532 & 0.212 & 0.833 & 0.0408 & 0.0625 & 0.652 & 0.518 \\
$1: 0.33: 3.7$ & 4 & 2.4594 & 0.4532 & 5.426 & 0.000 & 0.2019 & 0.0625 & 3.228 & 0.003 \\
$1: 1: 7$ & 5 & -0.7816 & 0.4532 & -1.724 & 0.094 & -0.0169 & 0.0625 & -0.270 & 0.788 \\
\hline
\end{tabular}

of Table 3 indicate the level of influence on the voids ratios. The negative sign refers to the reduction effect of voids ratio which represents here a mortar characteristic porosity. The use of artificial hydraulic lime CHB has a reduction effect superior than the hydrated lime. In fact, this reductive effect could be caused by rice husks ash, which is part of this industrial product, where their fineness and their reactivity have a leading role. The increase of fine aggregate in mortars is directly related to lower compactness and therefore higher voids ratio.

The results of the effects analysis on mortar capillarity coefficient that is defined by the slope of the line formed between the amount of water absorption at $10 \mathrm{~min}$ and $90 \mathrm{~min}$, shown in Table 4, allow to identify significant differences in mortar proportions 1:0.33:3.7. The parameter related to these proportions indicates that both the decreased of addition as fine aggregate amounts contribute to the significant reduction in the mortar capillary coefficient. On the other hand, the significant influence of this mortar proportion means that a reduction, around $71 \%$, of mortar capillarity coefficient was attained increasing the binders content.

Regarding the mechanical strengths at 28 days, the parameters of Table 5 shows the mortar compressive 
and flexure strengths increasing with the addition reduction; as well as hydrated lime also increases significantly the mortar flexure strength. Thus, it is possible to conclude that hydrated lime in the mortar proportion 1:0.33:3.7 provided the highest significant mechanical strengths. But, it is also clear that the increase of the mechanical strength comes from the decrease in the addition content that means a large presence of cement in the mortar.

The results of variables effects analysis on mortar water permeability are shown in Table 6. It is possible to identify that hydrated lime addition was the only significant variable. It means that a reduction of water permeability around $27 \%$ could be attained when the hydrated lime is incorporated in the rendering mortars.

The results of the soluble salt content (sodium sulphate) analysis recorded in Table 7 show that the permanence of the masonry panels in contact with water containing salt led to a widespread presence of sulphate in all studied mortars, even those who had little or no manifestation of efflorescence, indicating that in these cases, the crystallization of the salt was formed in the substrate zone and/or within the mortar.

In the specific case of reference mortar proportion 1:1:6, mortar proportion 1:0.33:3.7 and 1:1:14, which visually demonstrated high rate of efflorescence and crypto-efflorescence, high levels of sulphates in most of samples were also observed. This observation indicates that in these mortars, the water and salts reaches the outer surface of the wall, giving rise to crystallization. In mortar proportion 1:1:7, especially the mixtures composed by hydrated lime (CHA) and by quicklime paste $(\mathrm{CV})$, was visually observed a small sign of efflorescence and crypto-efflorescence. The CV rendering mortar showed the highest salt content of all mortars studied. In the specific case of CHB rendering mortar (1:1:7), although not outwardly demonstrating the crystalline salts formation, the salts were formed inside the mortar. In this case, it meets the objectives sought, that is, water contaminated by soluble salts disappears as vapor, leaving inside the pores the recrystallized soluble salts formations, not leading to the coating outer surface. Thus, for a long period of time, the efflorescence and/or crypto-efflorescence anomalies will not be observed.

Table 6 Results of variables effects analysis on mortar water permeability.

\begin{tabular}{llllll}
\hline Level effect & Column & Parameter & Std.Err & $t$ & $p$ \\
\hline CHA & 1 & -0.2797 & 0.1073 & -2.604 & 0.014 \\
CHB & 2 & 0.1352 & 0.1073 & 1.259 & 0.217 \\
$1: 1: 6$ & 3 & -0.1972 & 0.1315 & -1.499 & 0.144 \\
$1: 0.33: 3.7$ & 4 & -0.0272 & 0.1315 & -0.206 & 0.8374 \\
$1: 1: 7$ & 5 & -0.0205 & 0.1315 & -0.156 & 0.8768 \\
\hline
\end{tabular}

Table 7 Soluble salts concentrations in mortars.

\begin{tabular}{lll}
\hline Mortar proportions & Additions & $\% \mathrm{SO}_{4}$ \\
\hline \multirow{2}{*}{$1: 1: 6$} & $\mathrm{CHA}$ & 1.26 \\
& $\mathrm{CHB}$ & 1.55 \\
& $\mathrm{CV}$ & 1.03 \\
$1: 0.33: 3.7$ & $\mathrm{CHA}$ & 2.28 \\
& $\mathrm{CHB}$ & 1.13 \\
$1: 1: 7$ & $\mathrm{CV}$ & 0.11 \\
& $\mathrm{CHA}$ & 0.68 \\
\multirow{3}{*}{$1: 1: 14$} & $\mathrm{CHB}$ & 0.61 \\
& $\mathrm{CV}$ & 2.23 \\
& $\mathrm{CHA}$ & 0.88 \\
\hline
\end{tabular}




\section{Conclusions}

The main conclusions of the analysis of variance carried out on the tests results performed in this study are, in summary, the following:

In general, the change in fine aggregates quantities directly influences the mechanical strength of mortars, increasing the load capacity to compressive and tensile stresses inversely to the fine aggregates content. These variations are inverted due mainly to the fact that increasing the aggregate content leads to higher voids content with lower availability of binders (cement and addition) to fill the gaps, creating low compactness and internal cohesion. Thus, the rendering mortar mechanical strengths were reduced.

Whatever the type of addition, the capillary coefficients of rendering mortars were similar. The fine aggregate increasing leads to higher values of this coefficient, indicating that the higher porosity, existing due to the high void content, ends up determining a higher initial water absorption contacting the surface of the specimens.

The results of permeability tests by the pipe method indicated no influence of the fine aggregates amount but a significant influence of addition type. In this case, the hydrated lime addition had a significant contribution on the water permeability reduction.

From the analysis of variance, it was possible to observe that the rendering mortars with higher fine aggregates content present salts crystallization on surfaces much later on, indicating that largest voids longer retain the salts soluble therein, hindering and delaying the efflorescence formations.

Finally, taking into account the experimental results mainly concerning the water absorption properties measured in this study, it is attested the best performance of the CHA in the mortar proportion 1:0.33:3.7.

\section{References}

[1] Terra, R. C. 2001. "Levantamento de Manifestações Patológicas em Revestimentos de Fachadas das Edificações da Cidade de Pelotas." Dissertação de Mestrado em Engenharia Civil, UFRGS, Porto Alegre.

[2] ABNT (Associação Brasileira de Normas Técnicas). 1991. Cimento Portland Pozolanico. Rio de Janeiro: ABNT, julho 1991. NBR 5736. (in Portuguese)

[3] ABNT. 1987. Argamassa e Concreto Endurecidos-Determinação da Absorção de água por Imersão-Índice de Vazios e Massa Específica. Rio de Janeiro: ABNT, Março de 1987. NBR 9778. (in Portuguese)

[4] LNEC (Laboratório Nacional de Engenharia Civil). 2000. Definição de um Método de Ensaio de Absorção de água por Capilaridade para Amostras de Argamassa Irregulares e Friáveis. Lisboa: LNEC, Junho de 2000. Relatório 140/00-NCCt. (in Portuguese)

[5] ABNT. 1987. Argamassa e Concreto Endurecidos-Determinação da Absorção de água por Imersão-Índice de Vazios e Massa Específica. Rio de Janeiro: ABNT, Março de 1987. NBR 9778. (in Portuguese)

[6] ABNT. 1991. Concreto-Determinação da Resistência à Tração na Flexão em Corpos-de-Prova Prismáticos. Rio de Janeiro: ABNT, Dezembro de 1991. NBR 12142. (in Portuguese)

[7] LNEC. 2000. Desenvolvimento de um Ensaio para Avaliação da Resistência aos sais de Revestimentos por Pintura para Edificios Antigos. Lisboa: LNEC, Outubro de 2000. Relatório 240/00-NCCt. (in Portuguese)

[8] Polisseni, A. E. 1986. Método de Campo para Avaliar a Capacidade Impermeabilizante de Revestimentos de Parede-Método do Cachimbo. Dissertação de Mestrado em Engenharia Civil, Escola de Engenharia, UFRGS, Porto Alegre. (in Portuguese)

[9] ABNT. 1987. Agregados para Concreto-Determinação de sais, Cloretos e Sulfatos Solúveis. Rio de Janeiro: ABNT, Julho de1987. NBR 9917. (in Portuguese) 